\title{
KONDISI FISIK PEMAIN BOLA VOLI PADA KEGIATAN EKSTRAKURIKULER DI MTS ATTAUBAH
}

\section{PHYSICAL CONDITIONS OF VOLLEY BALL IN EXTRACURRICULAR ACTIVITIES AT MTS ATTAUBAH}

\author{
IDRIS SUPRIADI \\ Sekolah Tinggi Keguruan dan IImu Pendidikan Syekh Manshur \\ Jalan Raya Labuan km.5 Kadulisung Pandeglang \\ Ponsel: 081398896130 \\ Surel: idrissupriadi91@gmail.com
}

\begin{abstract}
Abstrak
Metode yang digunakan dalam penelitian adalah metode penelitian kualtitatif. Populasi dari penelitian adalah seluruh pemain bola voli di MTs Attaubah sebanyak 17 orang. Instrument yang diterapkan dalam penelitian ini adalah instrumen yang telah dibakukan dari beberapa sumber (buku) olahraga yang terkait dengan sub fokus yang diteliti. Berdasarkan hasil pengolahan data yang diperoleh saat penelitian peneliti mendapatkan hasil penelitian sebagai berikut : Daya tahan pemain berada dalam kategori sangat kurang dengan rata-rata capaian sebesar = 30,2 dengan persentase capaian $82,35 \%$. Daya ledak pemain berada pada kategori kurang sekali dengan kemampuan rata-rata 97,5 dengan persentase capaian $82,35 \%$. Kelincahan pemain berada pada kategori kurang dengan kemampuan ratarata 20,58 dengan persentase capaian $64,71 \%$. Sedangkan untuk keseimbangan pemain berada pada kategori kurang dengan kemampuan rata-rata 21,72 dengan persentase capaian $70,59 \%$. Secara keseluruhan berdasarkan penelitian tingkat kondisi fisik pemain bola voli MTs At-taubah berada dalama kategori kurang sekali dan kurang, hal ini meandakan bahwasanya pemain bola voli Mts At-taubah secara umum berada di bawah rata-rata. Hal ini bisa saja terjadi yang dipengaruhi oleh faktor-faktor baik eksternal dan internal. Oleh karena itu peningkatan seluruh aspek kondisi fisik harus ditingkatkan secara terstruktur dan sistematis.
\end{abstract}

Kata Kunci : Kondisi Fisik, Bola Voli

\begin{abstract}
The method used in this research is qualitative research method. The population of the study was all 17 volleyball players in MTs Attaubah. The instrument applied in this study was an instrument that had been standardized from several sports sources (books) related to the sub focus that was studied. Based on the results of data processing obtained during the research the researchers got the results of the study as follows: Endurance players are in the category of very less with an average achievement of $=30.2$ with a percentage of performance $82.35 \%$. The explosive power of players is in the category of very poor with an average ability of 97.5 with a percentage of achievements $82.35 \%$. Player agility is in the category of lacking with an average ability of 20.58 with a percentage of $64.71 \%$ achievement. As for the balance of players in the category of lacking with an average ability of 21.72 with a ercentage of achievements of $70.59 \%$. Overall, based on the research, the level of
\end{abstract}


physical condition of MTs At-taubah volleyball players is in the category of very poor and poor, this indicates that the volleyball player Mts At-taubah is generally below the average. This can happen that is influenced by factors both external and internal. Therefore improvement of all aspects of physical condition must be improved in a structured and systematic manner.

Keywords: Physical Condition, Volleyball

\section{PENDAHULUAN}

Kegiatan ekstrakurikuler
merupakan sarana yang diberikan
sepenuhnya kepada peserta didik
untuk meningkatkan bakat dan
kemampuan sesuai dengan
keinginannya masing-masing untuk
meraih prestasi paling tinggi dalalm
lingkungan sekolah, baik itu dalam
ranah seni, musik, sains dan olahraga. Diperlukan pembelajaran dan pelatihan yang sistematis dan terstruktur dalam untuk mendapatkan hasil yang maksimal. Olahraga prestasi dalam ranah sekolah menitik beratkan kepada prestasi maksimal yang bisa dicapai oleh atlet secara individu atau tim. Untuk mendapatka prestasi maksimal diperlukan latihan yang terstruktur, sistematis dan terpogram hal ini bertujuan untuk mengukur dan meningkatkan kemampuan baik dari segi kondisi fisik, teknik serta taktik dalam permainan secara teratur.

Kondisi fisik merupakan hal mutlak yang harus dimiliki oleh seorang atlet. Dengan kondisi fisik yang baik, atlet akan bisa menguasai teknik dan taktik selama melakukan pertandingan. Menurut Syafruddin (2005: 20) "kondisi fisik merupakan kemampuan dasar untuk mengembangkan prestasi olahraga. Tanpa adanya kondisi fisik, seorang atlet tidak bisa mencapai prestasi yang maksimal". Kutipan tersebut menjelaskan bahwa kondisi fisik adalah komponen yang sangat penting bagi seorang atlet untuk mencapai prestasi yang tinggi.

Baik atau tidaknya kondisi fisik seorang atlet mempunyai pengaruh besar untuk menguasai berbagai teknik dasar. Sesulit apapun teknik dalam permainan, bila didukung oleh kemampuan kondisi fisik yang baik, maka teknik itu bisa dikuasai. Untuk mendapatkan kondisi fisik yang baik, atlet harus latihan intensif dan tepat sesuai dengan cabang olahraga, umur, dan jenis kelamin, yang dipandu oleh pelatih yang berkompeten. Penguasaan Teknik yang baik sangat bergantung pada tingkatan kondisi fisik, semakin bagus kondisi fisik seseorang atlet maka semakin mudah bagi atlet tersebut 
meningkatkan teknik dalam permainan.

Teknik dalam permainan bola voli secara keseluruhan sangat bergantung kepada aspek-aspek kondisi fisik seperti para pemain harus memiliki daya tahan yang bagus agar bisa bertahan selama minimal 2 set dan maksimal 5 set dalam satu pertandingan, spiker dan bloker harus memiliki daya ledak, kecepatan, koordinasi, kelincahan dan kelincahan yang mumpuni untuk mendapatkan point secara maksimal dengan cara menjatuhkan bola dilapangan lawan bail itu dengan melalakukan serangan (spike) atau membendung serangan dari lawan (block), semakin tepat dan kuat pukulan dari spiker maka blocker lawan akan semakin sulit untuk mengantisipasi serangan, hal tersebut juga berlaku untuk kebalikannya dima semakin cepat dan bagus blocking maka akan semakin mudah untuk mengantisipasi berbagai serangan dari lawan. Cepat dapat diartikan pada saat satu tim menyerang pada saat yang bersamaan tim lain untuk bertahan sekaligus mendapatkan poin, Suardi (2019 : 95)

Kecepatan, koordinasi, daya ledak dan keseimbangan sangat diperlukan oleh seorang tosser/setter dalam merancang skema serangan yang akan dilakukan. Seluruh pola serangan yang bertujuan besar untuk mendulang poin demi poin dalam pertandingan tertumpu pada tosser/setter, tidak hanya itu jika berada di barisan depan maka setter juga bertanggung jawab untuk blocking terhadap serangan dari lawan. Untuk itu seorang setter harus memiliki seluruh aspek kondidi fisik diatas rata-rata karena pergerakan setter dalam permainan bisa mencapai dua kali lipat atau lebih dari pemain lainnya di dalam lapangan.

Menyusun pola serangan dalam permainan merupakan hal yang sangat krusial dalam permainan. Namun jika para pemain yanga berada dibarisan belakan tidak mampu memngembalikan bola dengan baik kepada seter baik itu dari servis ataupun spike dari pemain lawan maka seluruh pola serangan akan terputus dan kemungkinan mendapatkan poin akan semakin kecil. Banyak orang yang beranggapan bahwa permainan bola voli hanya berfokus terhadap serangan. Namun kenyataan nya pengembalian bola pada awal terhadap servis dan spike merupakan kunci utama dalam penyusunan berbagai pola serangan yang akan dilakukan. Karena dalam permainan 


\section{Cakrawala Pedagogik}

bola voli memiliki peratura dimana seluruh pemain harus melakukan rotasi maka setiap pemain harus memiliki kemampuan teknik dasar yang bagus dengan didasari aspekaspek kondis fisik diatas rata-rata.

\section{KAJIAN TEORETIK}

Kondisi fisik atlet memegang peran paling penting dalam menjalankan program latihannya agar bisa mencapai puncak dari prestasi masing-masing.

Program latihan kondisi fisik haruslah direncanakan secara baik, sistematis dan ditunjukan untuk meningkatkan kondisi fisik dan kemampuan fungsional dari system tubuh sehingga dapat menimbulkan atlet mencapai prestasi yang lebih baik sesuai harpan. Fisik seorang atlet juga menetukan prestasi atlet seperti yang dikatakan Suardi (2017:204) Dengan kondisi fisik yang baik, atlet akan bisa menguasai teknik dan taktik selama melakukan pertandingan. Kondisi fisik merupakan kemampuan dasar untuk mengembangkan prestasi olahraga. kondisi fisik merupakan satu kesatuan yang utuh yang tidak dapat dipisahkan, baik peningkatannya maupun pemeliharaannya, artinya bahwa komponen tersebut walaupun perlu dilakukan dengan prioritas.

Dalam teori latihan, disebutkan ada empat aspek latihan yang perlu diperhatikan dan dilatih secara seksama. Kondisi fisik merupakan salah satu aspek penting untuk meningkatkan prestasi olahraga, dengan melakukan latihan kondisi fisik memungkinkan kondisi siswa untuk dapat mengikuti program latihan dengan baik. Perkembangan kondisi fisik yang menyeluruh amatlah penting. Oleh karena itu tanpa kondisi fisik yang baik atlet tidak akan dapat mengikuti latihan-latihan dengan sempurna.

Seorang pemain bola voly memiliki kondisi fisik puncak dapat diartikan bahwa pemian tersebut mempunyai kesanggupan untuk bermain bola voly dengan efesien, tanpa mengalami kelelahan yang berarti setelah selesai bermain Pemain bola voly yang baik perlukan dukungan kondisi fisik yang baik. Kualitas kondisi fisik yang kurang baik tidak bisa mendukung pelaksanaan gerak yang sesuai dengan tuntutan permainan bola voly yang membutuhkan tenaga yang besar. Permain bola voly yang tidak memiliki kondisi fisik yang besar akan sulit untuk mencapai prestasi maksimal. 


\section{Cakrawala Pedagogik}

Kondisi fisik merupakan salah satu aspek latihan yang paling dasar untuk dilatih dan di tingkatkan, untuk mendapatkan kondisi fisik yang baik diperlukan persiapan latihan yang dapat meningkatkan dan mengembangkan kondisi fisik, daya tahan merupakan salah satu komponen fisik yang sangat penting untuk dilatih dan ditingkatkan menjadi stamina dalam upaya mencapai prestasi yang optimal.

\section{METODE PENELITIAN}

Penelitian ini menggunakan penelitian kualitatif karena didasari pada pengamatan terhadap kemampuan kondisi fisik pemain bola voli di MTs Attaubah tanpa ada campur tangan dari peneliti atau peneliti tidak memberikan treatment atau perlakukan terhadap peserta atu objek penelitian. Metode ini lebih peka dan dapat menyesuaikan diri dengan banyak penajaman pengaruh bersama terhadap nilai-nilai yang dihadapi Moloeng (2007 : 10).

Penelitian ini merujuk kepada tingkatan kondisi fisik pemain bola voli yang terdiri dari 18 orang. Penelitian kualitatif peneliti melakukan penelitian dengan skala yang lebih kecil, terhadap kelompok yang memiliki kekhususan tersendiri. Menurut
Sukmadinata (2009 : 99) "Kelompok yang diteliti bersifat alamiah dan saling keterkaitan secara individual ataupun kelompok".

Sebelum pelaksaan tes, tester harus memberikan penjelasan secara rinci tentang bentuk tes yang akan dilaksanakan agar tidak terjadi kekacauan atau kekeliruan pada saat melakukan tes yang sesuai dengan kriteria penilaian yaitu tes kondisi fisik. Tata cara pengambilan data dan penilaian terhadap kemampuan kondisi peserta dilakukan sesuai dengan penilaian menurut instrument masing-masing.

\section{HASIL DAN PEMBAHASAN}

Hasil tes dan pengukuran terhadap kemampuan kondisi fisik pemain bola voli MTs Attaubah yang terdiri dari daya tahan dengan menggunakan bleep test, daya ledak dengan menggunakan vertical Jump, kelincahan dengan Illinois agility run dan keseimbangan dynamic balance test akan disajikan secara tersusun berurutan sebagai berikut:

\section{Daya Tahan}

Bleep Test yang dilaksanakan untuk memperoleh data VO2Max atau kapasitas penyerapan oksigen maksimal dalam penelitian diperoleh 


\section{Cakrawala Pedagogik}

data sebagai berikut : skor maksimal $=39,9$ skor minimum $=23,3$ standar deviasi sebesar 4,65 dan varians 21,6 dan median $=29,5$. Data berdistribusi normal, karena selisih antara nilai mean (rata-rata) dengan nilai median tidak lebih dari satu standar deviasi. Dan dalam penelitian ini memperoleh rata-rata dari keseluruhan pemain berkisar pada angka 30,2 yang bisa masukan kedalam kategori kurang sekali.

Selanjutnya dilanjutkan dengan distribusi frekuensi data yang disesuaikan dengan norma atau ketetapan untuk pengukuran bleep test untuk lebih jelasnya akan disajikan table sebagai berikut :

Table 1. Frekuensi Kemampuan VO2Max

\begin{tabular}{|c|c|c|c|}
\hline Kategori & Norma & $\mathrm{Fa}$ & $\mathrm{Fr}$ \\
\hline $\begin{array}{c}\text { Kurang } \\
\text { Sekali }\end{array}$ & $<35$ & 14 & 82,35 \\
\hline Kurang & $35-37$ & 1 & 5,88 \\
\hline Cukup & $38-44$ & 2 & 11,76 \\
\hline Baik & $45-50$ & 0 & 0 \\
\hline $\begin{array}{c}\text { baik } \\
\text { sekali }\end{array}$ & $51-55$ & 0 & 0 \\
\hline Superior & $>55$ & 0 & 0 \\
\hline \multicolumn{3}{|c|}{ Jumlah } & 100 \\
\hline
\end{tabular}

Merujuk pada table frekuensi VO2MAX yang telah disajikan bisa juga digunakan dalam bentuk diagram

\section{Volume 4 Nomor 2 Oktober 2020}

batang yang bisa mempermudah untuk memahami data yang diperolehsebagai berikut:

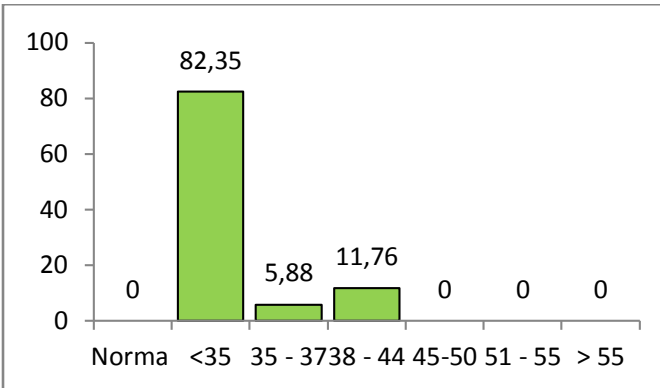

Gambar 1. Hasil Bleep Test

Sesuai dengan hasil tersebut bisa disimpulkan pemain mayoritas memiliki daya tahan aerobik pada kategori kurang sekali. Pelatih harus meningkatkan daya tahan secara keseluruhan, daya tahan merupakan aspek utama dalam permainan terutama bola voli yang umumnya menuntut pemain untuk bergerak dengan bola atau tanpa bola dan begerak secepat mungkin.

Dalam pertandingan dengan durasi waktu yang tidak bisa dipastikan daya tahan merupakan aspek terpenting agar pemain bisa bermain dengan baik dalam beberapa set untuk memenangkan pertandingan.

Dengan daya tahan yang bagus pemain bisa bertahan dari kelelahan dalam pertandingan. Kelelahan akan memberikan efek yang serius bagi 
seorang pemain seperti cidera, kurang konsentrasi, emosional dan human error.

Seseeorang yang memiliki daya tahan yang bagus akan bisa dengan mudah untuk menaikan kompone kondisi fisik lainnya dan bias dengan mudah meningkatkan keterampilan individu dan kelompok yang sangat mendukung untuk menciptakan permainan yang bagus, namun peatihan yang diberikan oleh pelatih juga harus sesuai dengan kriteria umur. Hal ini bertujuan untuk latihan yang diberikan tidak akan mempengaruhi tumbuh kembang anak dan cidera yang akan diterima jika memberikan beban latihan yang terlalu berat (Overload Training).

\section{SIMPULAN}

Berdasarkan dari hasil penelitian yang dilaksanakan di MTs Attaubah dapat ditarik kesimpulannya daya tahan pemain bola voli MTs Attaubah berada dalam kategori kurang sekali, hal ini sangat memperihatikan, karena daya tahan merupakan pondasi utama untuk meningkatkan komponen kondisi fisik lainnya dan meningkatkan teknik dasar. Dengan kondisi fisik yang bagus maka pemain akan bisa melakukan dan meningkatkan keterampilan dan komponen kondisi fisik secara khusus, hal ini akan mengoptimalisasi peningkatan peforma secara berkala dan berkelanjutan, tentunya dengan adanya latihan yang terprogram dan berjalan secara teratur dan berkelanjutan.

\section{DAFTAR PUSTAKA}

Ahmadi, Nuril. Panduan Olahraga Bola Voli. Solo : Era Pustaka Umum, 2007

Arikunto, Suharsimi. Prosedur penelitian Suatu Pendekatan Praktik. Edisi Revisi. Jakrta : Rineka Cipta, 1996

Arsil, Pembinaan Kondisi Fisik. SUKABINA Copy Center, 2009.

Dinata, Marta. Rahasia sang Juara Menuju Prestasi Dunia. Jakarta : Cerdas Jaya, 2005.

Irawadi, Hendri. Kondisi Fisik dan Pengukurannya. Padang. UNP, 2013

Ma'mun, Amung dan Subroto. Pendekatan Keterampilan Taktis dalam Permainan Bola Voli. Direktorat Jendral Olahraga, 2001

Muhajir. Pendidikan Jasmani Olahraga dan Kesehatan. Bandung, Erlangga 2004 
Munasifah, Bermain Bola Voli.

Semarang-Demak : CV. Aneka

IImu, 2009

Moleong, Lexy. J. Metodologi

Penelitian Kualitatif. Bandung :

Remaja Rosdakarya. 2007

Suardi, Devaron. Analisis Kebutuhan

Keterampilan Bertahan dalam

Permainan Bolavoli.

Cakrawala Pedagogik,

Staisman Press. Vol 3 (2)

2019.

Suardi, Devaron. Tinjauan Kondisi

Fisik Atlet Bolabasket Putra

Sman 1 Koto XI Tarusan.

Cakrawala Pedagogik,

Staisman Press. Vol 1 (2)

2017

Sudjana, N. Dasar-Dasar Belajar Mengajar. Bandung :Sinarbaru, 1989

Suharno,HP. IImu Kepelatihan Dasar.

Surakarta : Universitas

Sebelas Maret Press, 1993

Syafruddin. IImu Kepelatihan

Olahraga. Padang: Fakultas

IImu Keolahragaan UNP, 2011.

Widiastuti. Tes dan Pengukuran Olahraga. Jakarta, PT Raja Grafindo Persada, 2015

Yunus, M. Olahraga Pilihan Bola Voli. Jakarta : Depdikbud Dikjen Dikti. 1992 